\title{
A revised key to the Neotropical cleptoparasitic anthidiine genera (Hymenoptera, Megachilinae) with notes and description of the male of Rhynostelis Moure \& Urban
}

\author{
Danúncia Urban ${ }^{1, \dagger}$, Daniele Regina Parizotto ${ }^{1, \ddagger}$ \\ I Laboratório de Biologia Comparada de Hymenoptera, Departamento de Zoologia, Universidade Federal do \\ Paraná, Caixa Postal 19020, 81531-980, Curitiba, Paraná, Brazil
}

Corresponding author: Daniele Regina Parizotto (dparizotto@gmail.com)

Academic editor: M. Engel | Received 24 September 2012 | Accepted 27 November 2012 | Published 7 December 2012

Citation: Urban D, Parizotto DR (2012) A revised key to the Neotropical cleptoparasitic anthidiine genera (Hymenoptera, Megachilinae) with notes and description of the male of Rhynostelis Moure \& Urban. ZooKeys 249: 27-35. doi: 10.3897/ zookeys. 249.4030

\begin{abstract}
Rhynostelis Moure \& Urban is a monotypic cleptoparasitic neotropical anthidiine genus currently known from two females. Herein, we describe and illustrate for the first time the male and its genitalia and it is confirmed that Rhynostelis parasitizes nests of Eufriesea. An identification key to the genera of cleptoparasitic anthidiine from the Neotropical region is also presented.
\end{abstract}

\section{Keywords}

Anthidiini, Brazil, cleptoparasitism, host, taxonomy

\section{Introduction}

Cleptoparasitism is a common behavior among species of Anthidiini and presumably evolved multiple times within the tribe (Gonzalez et al. 2012). This condition is currently known in eleven genera worldwide, seven of which occur in the neotropical region, Austrostelis Michener \& Griswold, 1994; Dolichostelis Parker \& Bohart, 1979; 
Heterostelis Timberlake, 1941; Hoplostelis Dominique, 1898; Rhynostelis Moure \& Urban, 1995; Stelis Panzer, 1806; and the recently described Melostelis Urban, 2011, which is known from a single female from the Amazon (Michener 2007, Moure \& Urban, 2007). In the classification proposed by Michener (2007), Austrostelis, Hoplostelis and Stelis are treated as genera, with remaining taxa treated as subgenera. In this contribution, all taxa are treated at the generic level, according to the classification of Urban and Moure (2007).

Little is known about the biology of these cleptoparasitic bees. In some genera, as Hoplostelis and Dolichostelis, the female enters the nest of a host and kills its eggs and/or larvae. In other groups, such as Stelis, the female lays her eggs on the nest while still open and the young larva has mandibles adapted to kill the host egg or larva (Michener 2007). Cleptoparasitic Anthidiini mostly parasitizes other Anthidiini, but they can also parasite other Megachilinae genera well as Euglossini (Apinae). Austrostelis was recorded by Zanella and Ferreira (2005) from a nest of Epanthidium tigrinum (Schrottky, 1905); Hoplostelis is known to parasitize the orchid bee Euglossa cordata (Linnaeus, 1758) (Bennett 1966); Dolichostelis is cleptoparasitic in nests of Megachile Latreille, 1802, probably of the subgenus M. (Chelostomoides) Robertson, 1901 (Parker and Bohart 1979); Stelis parasitizes several genera of Megachilinae: Anthidiellum Cockerell, 1904, Anthidium Fabricius, 1804, Ashmeadiella Cockerell, 1897, Chelostoma Latreille, 1809, Heriades Spinola, 1808, Hoplitis Klug, 1807, Megachile Latreille, 1802 and Osmia Panzer, 1806 (Michener 2007); Heterostelis is known to parasitize species of Trachusa Panzer, 1804 (Thorp 1966 and Michener 2007).

Rhynostelis consists of a single species, $R$. multiplicata (Smith, 1879), which is known from two female specimens collected on the State of Amazonas, Brazil. Herein, we present an updated diagnosis of Rhynostelis, describe and illustrate the male of $R$. multiplicata and, based on two specimens collected from a trap-nest, we record the orchid bee Eufriesea laniventris (Ducke, 1902) as its host. A key to all neotropical cleptoparasitic anthidiine genera is also provide.

\section{Material and methods}

Morphological terminology follows Michener (2007) and that for mandibles Michener and Fraser (1978). Measurements are given in millimeters and were taken using an ocular micrometer on a stereoscopic microscope Leica MZ125. Total length was measured in lateral view, from the head to the apex of metasoma; length of forewing was measured at the anterior margin, from the costal sclerite to the wing apex. The illustrations were obtained with a Leica DFC 500 digital camera attached to the stereoscopic microscope Leica MZ 16 and combined with the software AUTO-MONTAGE PRO. All material used in this study is deposited in the Coleção Entomológica Pe. Jesus Santiago Moure, Universidade Federal do Paraná, Curitiba, Brazil (DZUP). 


\section{Taxonomy}

\section{Rhynostelis Moure \& Urban, 1995}

http://species-id.net/wiki/Rhynostelis

Figs $1-7,15,17$

Rhynostelis Moure \& Urban, 1995: 297.

Hoplostelis (Rhynostelis) Michener, 2007: 518.

Male description. Diagnosis. Mandibles with only apical tooth elongated, upper distal angle rounded (Fig. 2); clypeus protuberant, with a basal tubercle at middle; supraclypeal area protuberant (Fig. 1); scutum and scutellum bigibbous; axillae and dorsoventral area of mesepisternum gibbous (Figs 3, 5); distal tergum short and sinuous at middle (Fig. 6); sternum sixth with laminar rounded, lateral projections.

Description. Mandibles with distal margin almost straight, only with apical tooth elongated; upper distal angle slightly marked, condylar carina elevated and strongly laminated, slightly wider at base (Fig. 2). Clypeus protuberant with median basal tubercle elongated, extended in low irregular carina in basal half, apex depressed without projections, not exceeding labrum, covered by many long hairs. Labrum weakly bilobed near clypeal base. Supraclypeal area with wide, somewhat flat median carina; frons with long, well marked carina. Juxtantennal carina laminated, ventrally short, not arising at base of antennal sockets and extending upward (Fig. 1). Scutum and scutellum bigibbous; axillae gibbous; base of propodeum with irregular foveae (Fig. 3, 5). Omaulus lamellate, almost extending ventrally; mesepisternum with gibbous area near mesocoxal cavity. Fore and middle tibiae with midapical spine on outer surface (Fig. 15); arolia present. Fifth and sixth terga with transverse, median low carina; sixth tergum with apical projection at middle; distal tergum slightly emarginated at apex (Fig. 6). Second sternum enlarged, with apex weakly emarginated at middle, with long pilosity at apex; third to fifth sterna with dense apical pilosity, laterally with longer and curved hairs; sixth sternum with distal margin almost straight, with large, angled, laminar, lateral projections subapically.

Genitalia. Gonostylus slightly longer than penis valves; apical half with dense and long pilosity on inner margin; apex rounded, laterally slightly convex. Gonobase incomplete dorsally, only visible laterally (Fig. 7).

Comments. Moure and Urban (1995) mentioned that the base of the propodeum in Rhynostelis lacks foveae. Michener (2007), also pointed out this feature as one of the characteristics that separates Rhynostelis from Hoplostelis. However, a reexamination of Rhynostelis specimens revealed the presence of irregular fovea in the base of its propodeum, which are difficult to see due the shiny yellow integument. Michener (2007) considered Rhynostelis as a subgenus of Hoplostelis and in his key, the male agrees with the female by the characters he listed, except for the absence of foveae in the base of propodeum, as commented above. The male of Hoplostelis further differs from Rhynostelis by the following combination of characters: three 
strong mandibular teeth and two basal depressions near the articulation of the head; omaulus carinate only in the dorsal one-half or one-third; sixth sternum with narrow lateral projections and without gibbous mesosoma.

\section{Rhynostelis multiplicata (Smith, 1879)}

http://species-id.net/wiki/Rhynostelis_multiplicata

Figs $1-7,15,17$

Anthidium multiplicatum Smith, 1879: 87.

Rhynostelis multiplicata; Moure and Urban 1995: 298.

Hoplostelis (Rhynostelis) multiplicata; Michener 2007: 518.

Diagnosis. Integument black, with wide yellow areas in both sexes. Scutum with a large, reverse U-shaped macula; scutellum almost totally yellow; axillae yellow and all terga with yellow bands (Figs 3, 4). Male and female with protuberant clypeus.

Male description. Approximate body length 13.29; forewing length 10.45; head width 4.02; head length 3.67; eye length 2.55. Head integument yellow except: distal margin of mandible and apical tooth black; labrum blackened; frons black, bands above superior margin of antennal sockets extending to vertex, including ocelli and finely attached with black spot above compound eyes. Antennae with ventral face of pedicel darkish yellow, remaining segments light brown; dorsal face with scape and pedicel light brown and flagellum amber (Figs 1,2). Pronotal lobe yellow; scutum black with large reverse U-shaped yellow maculae; scutellum with on yellow gibbous area joined medially by fine yellow band; axillae yellow; metanotum brown and propodeum yellow. Mesepisternum and metepisternum yellow; mesepisternum with discal black spot, metepisternum with ventral area black. Tegula amber and wing membrane brown. Legs almost totally yellow; middle tibiae with internal darkish area and hind tibiae with large internal darkish area (Figs 3, 4, 5). Terga black; basal tergum with yellow band slightly angled at middle; second to fourth with large yellow band, slightly narrower and slightly interrupted medially; fifth tergum with yellow band emarginated at middle on posterior margin; sixth tergum with yellow band, wider medially; distal tergum with subapical yellow band and blackish margin (Fig. 6). Two basal sterna yellow, with large translucent margin; third to fifth yellow with black infumated area on apical half; sixth sternum with large median black apical spot.

Pubescence. Light yellow with predominantly short hairs (less than ocellus diameter). Pilosity longer and denser among ocelli, above antennal sockets and clypeus apex. Hairs of mesepisternum little longer than mesoscutum, curved on scutellum and propodeum. Fore leg with coxa and trochanter covered by dense pilosity. Third to fifth sterna with apical dense and long slight curved hairs.

Sculpturing. Head finely punctate with sparser punctures on clypeal protuberance and at supraclypeal area. Mandibles with punctures smaller than that of head. Mesoscutum with integument microreticulated, punctures deeper than head. Gibbous area 

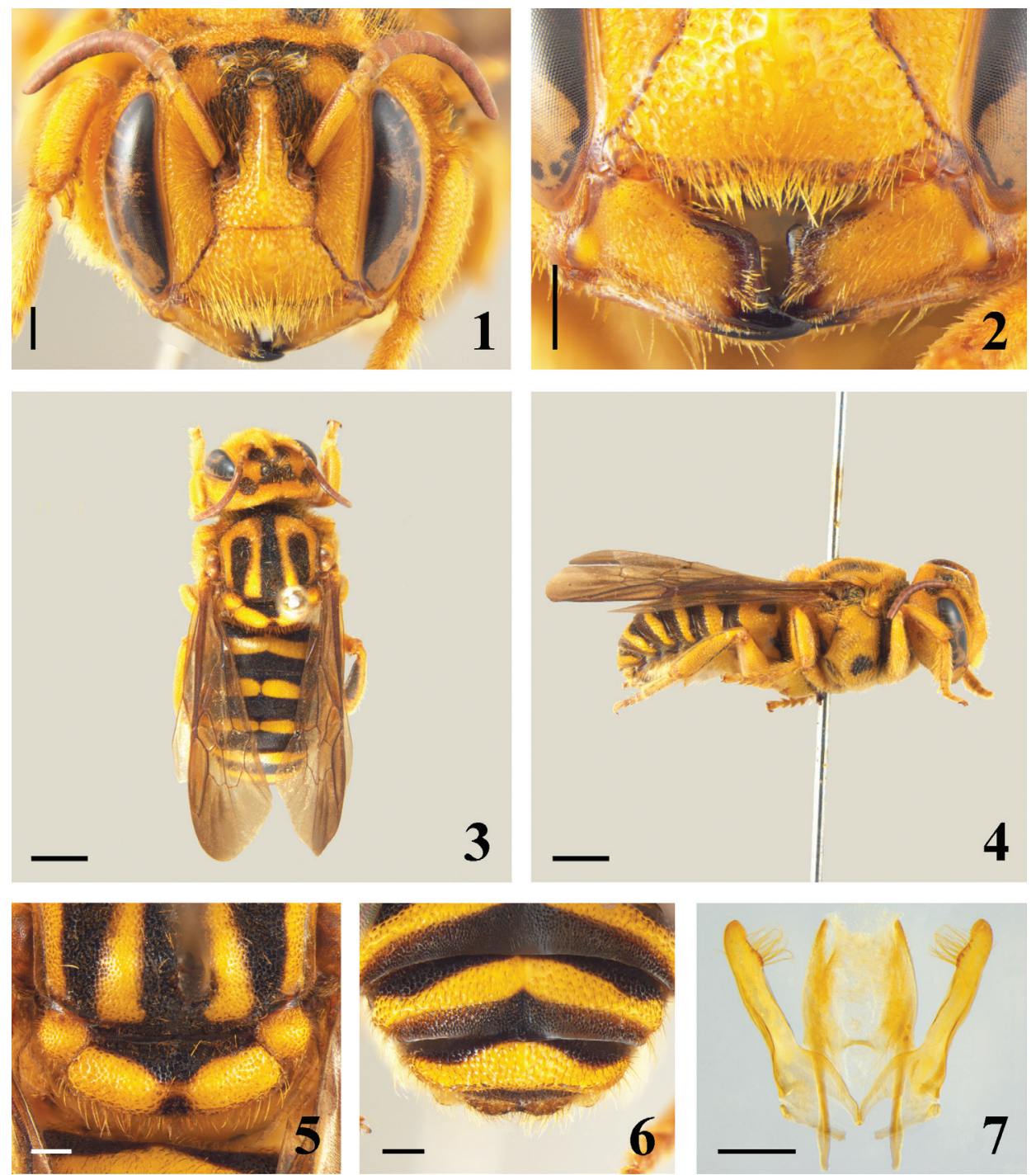

Figures I-7. Male of Rhynostelis multiplicata. I head in frontal view $\mathbf{2}$ detail of mandibles $\mathbf{3}$ dorsal view $\mathbf{4}$ lateral view $\mathbf{5}$ detail of scutellum $\mathbf{6}$ apex of metasoma $\mathbf{7}$ male genitalia in dorsal view. Scale line $=0.5$ $\mathrm{mm}$ (Figures 1-2, 5-7). Scale line $=2.0 \mathrm{~mm}$ (Figures 3-4).

of mesepisternum with larger and sparser punctures; distance between punctures at least half width a puncture diameter. Punctures of terga fine and shallow; punctures on yellow bands larger and sparser than those on black areas.

Material examined. BRAZIL, Pará, Belém: one male, "IPEAN [Instituto de Pesquisas e Experimentação Agropecuária do Norte, Belém] / 105-2 / EU” (DZUP); and one female "IPEAN / 105-1/ EU" (DZUP). Amazonas, Manaus: one female "Proj. DBFF.WWF/ Manaus-AM/ Brasil 04/11/89 / M. B. V. Garcia (DZUP). 

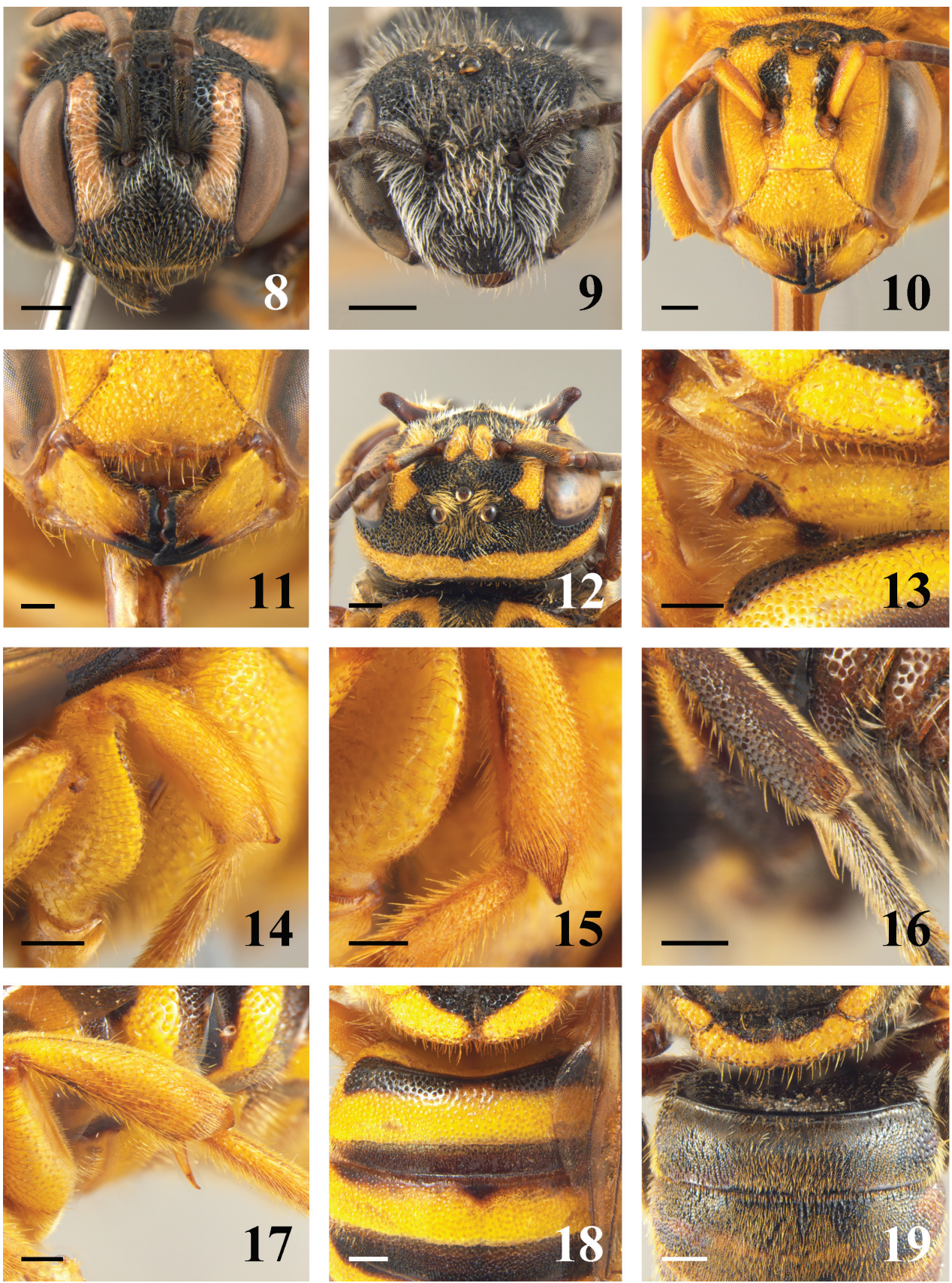

Figures 8-19. 8-10 head in frontal view of female. 8 Dolichostelis louisae 9 Stelis lateralis $\mathbf{1 0}$ Melostelis amazonensis II details of mandibles of Melostelis amazonensis $\mathbf{I} \mathbf{2}$ vertex of Hoplostelis bilineolata $\mathbf{3}$ fovea of propodeum of Melostelis amazonensis 14-15 middle tibia of female 14 Melostelis amazonensis 15 Rhynostelis multiplicata $\mathbf{1 6 - 1 7}$ hind tibia of female $\mathbf{1 6}$ Hoplostelis bilineolata $\mathbf{1 7}$ Rhynostelis multiplicata 18-19 details of first tergum of metasoma of female 18 Melostelis amazonensis 19 Hoplostelis bilineolata. Scale line $=0.5 \mathrm{~mm}$ (Figures 8-19). 
Remarks on the female from Pará. Approximate body length 16.13; forewing length 12.38; head width 4.90; length head 4.16, eye length 3.18. Integument predominantly yellow. The female differs from the male as follows: black maculae on vertex and frons larger than in male. All terga with yellow bands; basal tergum with complete band; second and third terga with bands slightly interrupted at middle; fourth tergum with band interrupted anteriorly only at middle, fifth tergum with band interrupted only posteriorly at middle; sixth tergum with subapical band and blackish margin. All sterna yellow; distal sternum with medioapical spot and black margin. The female collected in Manaus is a little smaller than the female from Belém and the integument of the head is darker and with irregular macula. Such differences in color might be caused by some chemical product used during collection or preservation.

Host records. Urban \& Moure (1995) commented that one female of $R$. multiplicata emerged from a test-tube placed on a termite nest where an orchid bee was previously seen (possible Eufrisea pulchra (Smith, 1854)). However, the record of the host was never confirmed. The specimens from Belém studied herein emerged from one nest of Eufriesea laniventris (Ducke, 1902), (DZUP), according the identification of Dr. Gabriel A. R. Melo. Thus, the cleptoparasitism of R. multiplicata on orchid bees of the genus Eufriesea is confirmed.

\section{Identification key to the neotropical cleptoparasitic genera of Anthidiini}

1 Juxtantennal carina absent; middle tibia with two widely separated apical

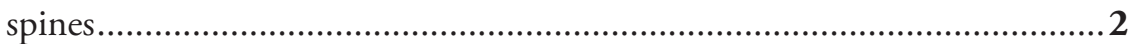

- Juxtantennal carina present; middle tibia with one apical spine, or subapical

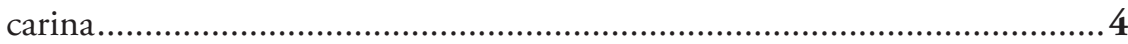

2(1) Hind tibia with subapical spine near posterior margin, sometimes completely hidden by dense hairs; hind basitarsus with carina along inner dorsal angle, separated from margin by a longitudinal depression

Heterostelis

- $\quad$ Hind tibia without subapical spine; hind basitarsus without carina.............. 3

3(1) Anterior surface of mesepisternum with punctures sparser than on lateral surface; omaulus carinate; interalveolar area short and protuberant (Fig. 8). Male: third sternum with pair of translucent lobes; forth sternum with two median projections

Dolichostelis

- Mesepisternum uniformly punctate; omaular carina absent; interalveolar area flat (Fig. 9). Male: third sternum not modified and fourth sternum with a setose medioapical projection

Stelis

4(1) Body relatively elongated; small-sized species. Integument coarsely punctate; pilosity between ocelli not differentiated from remaining areas of head

Austrostelis

- Body robust, metasoma almost globose, large species (Fig. 3, 4). Integument with fine to moderate-sized punctures; pilosity among ocelli longer than in remaining areas of head (Fig. 12) 5 
5(4) Scutellum laterally with laminate distal margin, with punctures at least twice as larger as those on scutum; hind tibia without flat apical projection on outer surface (Fig. 16); basal tergum with transverse carina (Fig. 19) .... Hoplostelis

- $\quad$ Scutellum without laminate projection, with punctures about as large as those on scutum; hind tibia with flat apical projection on outer surface (more developed in females) (Fig. 17); basal tergum without carina (Fig. 18) .......6

6(5) Frons not carinate; clypeus without basal tubercle and with two apical projections (Fig. 10). Mesosoma not gibbous; postspiracular fovea drop-shaped, microreticulated, coarsely punctuate and with irregular alveoli (Fig. 13). Female: mandible without bifurcated condylar carina and without protuberance near anterior articulation (Fig. 11); fore and middle tibiae with apical spine as long as half width of median ocellus diameter (Fig. 14) ... Melostelis

- $\quad$ Frons carinate; clypeus with basomedian tubercle and without apical projections (Fig. 1). Scutum and scutellum bigibbous (Fig. 5); postspiracular fovea rectangular and with regular alveoli. Female: mandible with bifurcated condylar carina elevated and with protuberance near anterior articulation; fore and middle tibiae with apical spine as long as a diameter of median ocellus (Fig. 15)

Rhynostelis

\section{Acknowledgements}

We are grateful to Dr. Domiciano Dias for the loan and donation of the specimens of Rhynostelis multiplicata. We would like to thank Dr. Gabriel A.R. Melo for identification of Eufriesea laniventris and information about the trap-nest. We also thank Vitor A. Nardino (Rede Paranaense de Coleçóes Biológicas - Taxon Line Project) for the photographs used here; Dr. Paschoal C. Grossi and Dr. Victor H. Gonzalez for the English corrections and comments of an earlier version of the manuscript. This is the contribution number 1883 of the Departamento de Zoologia, Universidade Federal do Paraná. DRP received a fellowship grant by CNPq, process number 163133/2011-5.

\section{References}

Bennett F D (1966) Notes on the biology of Stelis (Odontostelis) bilineolata (Spinola), a parasite of Euglossa cordata (Linnaeus). Journal of the New York Entomological Society 74: 72-79.

Gonzalez VH, Griswold T, Praz CJ and Danforth BN (2012) Phylogeny of the bee family Megachilidae (Hymenoptera: Apoidea) based on adult morphology. Systematic Entomology 37: 261-286. doi: /10.1111/j.1365-3113.2012.00620.x

Michener CD (2007) The Bees of the World [2nd Edition]. Johns Hopkins University Press; Baltimore, MD; xvi+[i]+953 pp., + 20 pls.

Michener CD, Fraser A (1978) A comparative anatomical study of mandibular structure in bees. The University of Kansas Science Bulletin 51: 463-482. 
Moure JS, Urban, D (1995) [1994] Rhynostelis, gen. n. e notas sobre Hoplostelis Dominique (Hymenoptera, Apoidea, Megachilidae). Revista Brasileira de Zoologia 11: 297-302. doi: 10.1590/S0101-81751994000200014

Parker FD, Bohart G E (1979) Dolichostelis, a new genus of parasitic bees. Journal of the Kansas Entomological Society 52: 138-153.

Thorp RW (1966) A synopsis of the genus Heterostelis Timberlake. Journal of the Kansas Entomological Society 39: 131-146.

Urban D, Moure JS (2007) Anthidini. In: Moure JS, Urban D, Melo GAR (Eds) Catalogue of bees (Hymenoptera, Apoidea) in the Neotropical region. Curitiba: Sociedade Brasileira de Entomologia, 875-913. Also available at: www.moure.cria.org.br/catalogue

Urban D (2011) Melostelis gen. nov., espécies novas e notas complementares sobre Anthidiini (Hymenoptera, Apidae). Revista Brasileira de Entomologia 55(2): 219-225. doi: 10.1590/ S0085-56262011005000013

Zanella FCV, Ferreira AG (2005) Registro de Hospedeiro de Austrostelis Michener \& Griswold (Hymenoptera: Megachilidae) e de sua Ocorrência na Caatinga. Neotropical Entomology 34(5): 857-858. doi: 10.1590/S1519-566X2005000500022 